\title{
Suggestive Measures Travel Time and Congestion Under Heterogeneous Traffic Conditions Connecting Chaheru-Phagwara
}

\author{
Sameer Ahmad Chadoo \\ Department of Civil Engineering \\ Lovely Professional University, Punjab, India \\ Ankit Bansal \\ Department of Civil Engineering \\ Lovely Professional University, Punjab, India \\ Farhaad Nazir \\ Department of Civil Engineering \\ Lovely Professional University, Punjab, India
}

\begin{abstract}
Movement in urban areas effectively affects both well-being and traffic situation. More the congested activity, greater the rate of auto-movement will have more regrettable impacts. The impacts can be decreased by movement diminishment, or by moving from autos and bicycles to alternate methods of transport with less negative effects. For this venture, the range for the study which $I$ have taken is Phagwara, Jalandhar. The purpose of the study is to control traffic jams on roads due to increase in the number of vehicles and saving the time of the people at the intersections. Travel time data is vital segment of numerous smart transportation frameworks (ITS) applications. As of late, the quantity of vehicles in India has been expanded enormously, prompting extreme movement blockage and pollution in an urban range, generally within peak periods. If we mitigate the congestion, another things will also decrease like pollution will be less and reduction in accident rate due to less delay to the road users. An attractive system to manage such issues is to move more individuals from personal vehicles to open transport by giving better administration like solace and less travel time. In this circumstance, propelled open transportation frameworks (APTS) are a standout amongst the most essential ITS applications, which can completely add to the movement circumstance in India. But this is not possible in every city because India is developing country and weak economy. Our point was to work out the traveler auto unit PCU for various categories of vehicles under non-homogeneous movement conditions. From the study we perceived that traffic volume was increasing ominously with mixed traffic conditions on the roadway consisting of Six-Lane-Two-Way traffic. The relation between volume and speed represents a third and fourth degree curve.
\end{abstract}

Keywords: Congestion, Mitigation, Highway capacity, PCU factor, ITS, Pollution, APTS.

\section{INTRODUCTION}

Travel time information is an essential component of many intelligent transportation systems (ITS) applications. Belonging to a period of time not long ago, the number of vehicles in Phagwara (India) has been increased in a very great amount, leading to highly developed traffic congestion and pollution in urban areas, particularly during peak periods. If we have a look on year wise increased number of vehicles from 1995 to 2007 as per district transport officer, Jalandhar. In 1995 [1] the number of vehicles in Phagwara area were 18532 and 38020 in 2007, which means there is more than $51 \%$ of increasing number of vehicles. Out of which growth of four and two wheelers are observed to be $42 \%$ which means that we need to focus on four and two wheelers most. A useful strategy is to deal with such issues is to change or shift more people from personal vehicles to public transport by providing better service, anxiety, freedom from effort.

Traffic activity in urban areas or a specific town has negative or undesirable consequences for wellbeing and nature. The more swarmed or congested the movement and the greater the extent of car activity, the more terrible or substandard these impacts appear in future. The development in urban activity clog has been perceived as a difficult issue in all vast metropolitan ranges in the nation, with critical impact on the economy, travel behavior, land use and a reason for inconvenience for a huge number of drivers. Despite the fact that movement clog is not a new problem in urban regions, it has been reached out to rural ranges sooner than anticipated. According to recent study conducted by transport cooperation of India. India faces a loss of $\$ 10.8$ billion a year due to congestion 


\section{LITERATURE REVIEW}

Arnott, R, and Small, K.A., 1994 [2] The assumption behind the street pricing suggests that, in order to achieve social best possible, a tax needs to be charged which must be equivalent to the difference between social subsidiary costs which include external costs that street users require on each other on a jam-packed road and personal or private average costs of users like travel delays, fuel, maintenance etc

Schrank and Lomax, 2005 [3] Travel Time Index was suggested in the urban mobility report index associates peak period travel and free flow travel while accounting for both periodic and incident conditions. They additionally evaluated that 90 percent of aggregate blockage costs in major urban zones are credited to travel delay, with the other 10 percent ascribed to fuel cost.

Khaled, 2006 [4] found that the significance towards civic transportation automobiles by giving main concern to buses, these can significantly trim downs the use of private vehicles.

Al-Ghamdi [5] collected the spot study data on roads of Riyadh and found 85th speed percentile for regression modeling gives much better estimates than those from the normal approximation model, while as on the other hand around $90 \%$ of motorists were exceeding the speed limits, indicating that much more speed limit enforcement is needed.

For commercial vehicles, alternatively, value of journey time is not solely dependent on the same parameters identified to be important for commuters. Since commercial are also a part of a business activity, they have several other criteria to consider for their departure time and route choices. They have to make profit therefore any kind of costs related to their trips (e.g. fuel, toll, delay penalties) not only affect their time savings (which is the case for commuters) but also affects their overall budget.

\section{SCOPE AND OBJECTIVES}

The particular objectives of the research work are as follows

- Controlling the traffic jams on roads due to increase in the number of vehicles.

- Saving the time of the people at the intersections.

- To collect traffic data like; traffic volume, speed, capacity.

- To regulate the capacity and level of service for a given stretch of the road.

\section{STUDY AREA}

This is the study area which we have taken is shown in the map below. LPU is situated at Chaheru, is one of the famous village as more number of NRI's belong to that village. Phagwara is a developing city as more number of vehicles are registered in the area.

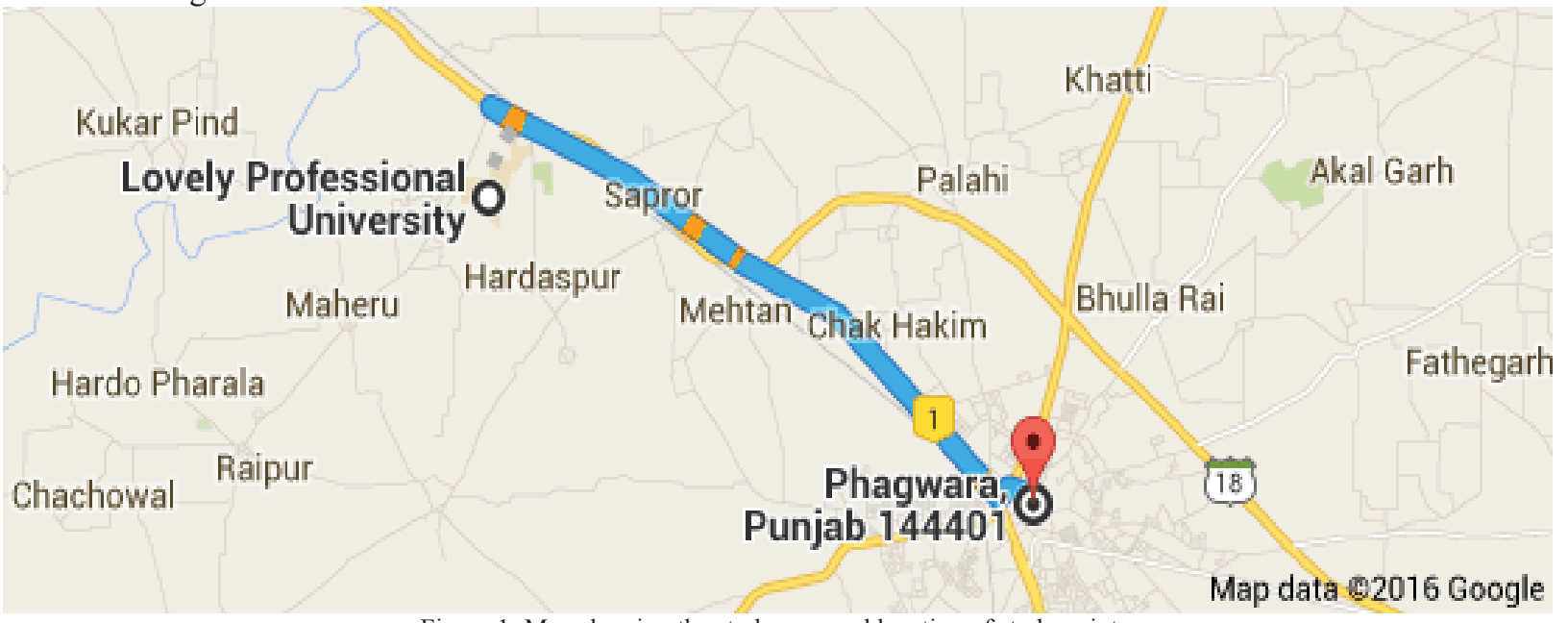

Figure 1: Map showing the study area and location of study points. 


\section{METHODOLOGY}

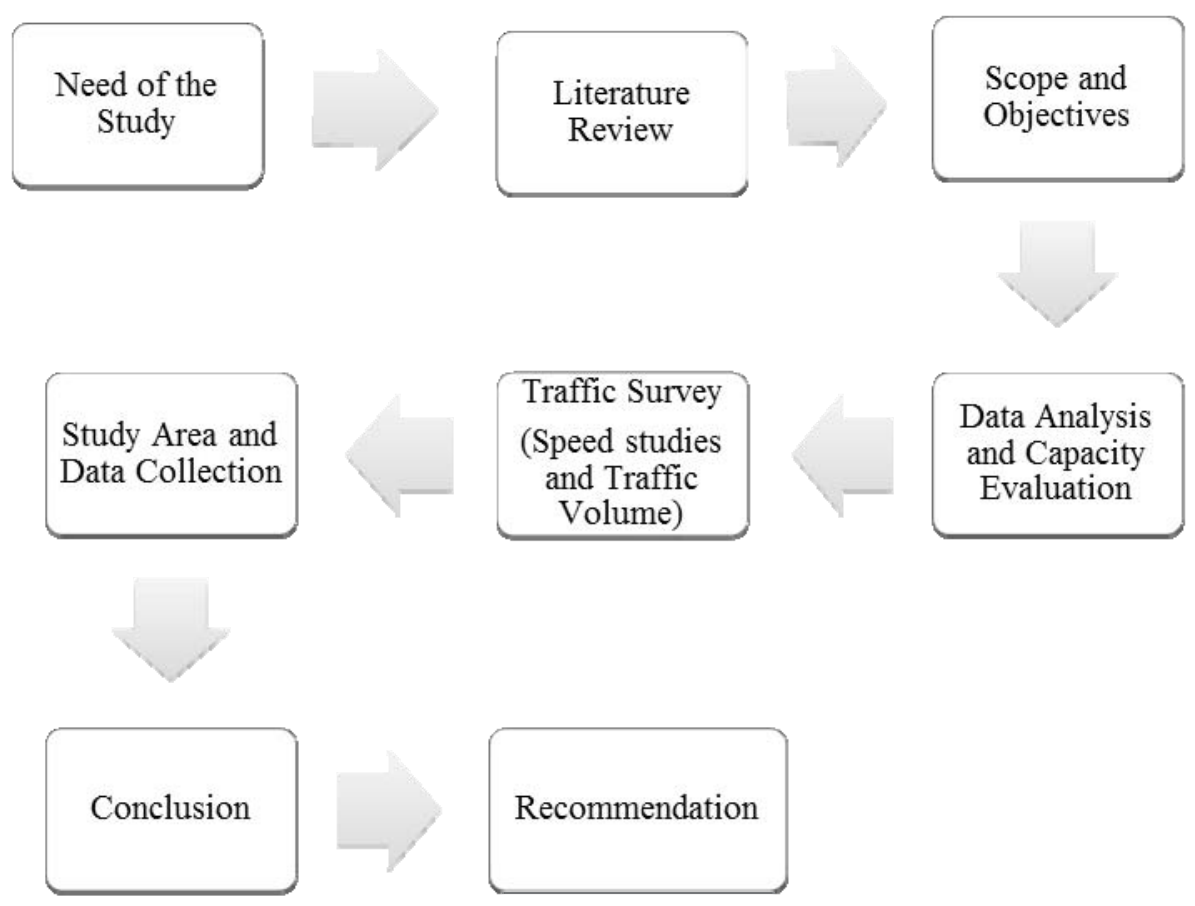

\section{DATA COLLECTION AND ANALYSIS}

In this study, we have find two types of data, traffic study data by spot-watch technique during off peak hours from 11:30 am-01:0 pm and traffic volume data by video photography method and later it was analysed by naked eye. The data was collected 12 hours hourly basis for week and weekend days.

\section{TRAFFIC VOLUME STUDY}

\section{Chaheru-Phagwara and Phagwara-Chaheru}

The main purpose of traffic volume study is used in creating new facilities, planning, reducing congestion. The data was collected for $12 \times 7$ for a complete week for both sides of the traffic flow, at urban mid-block section of ChaheruPhagwara road. It has been observed that for week days (Monday, Tuesday, Wednesday and Thursday) there were a slight change in traffic volume, so we had put the data for Monday only. For the weekend days (Friday, Saturday and Sunday) there were also a slight change observed. Here we the data for Saturday only. The data was collected during day time for 12 hours and it was analysed with the help of pie charts and graphs. 


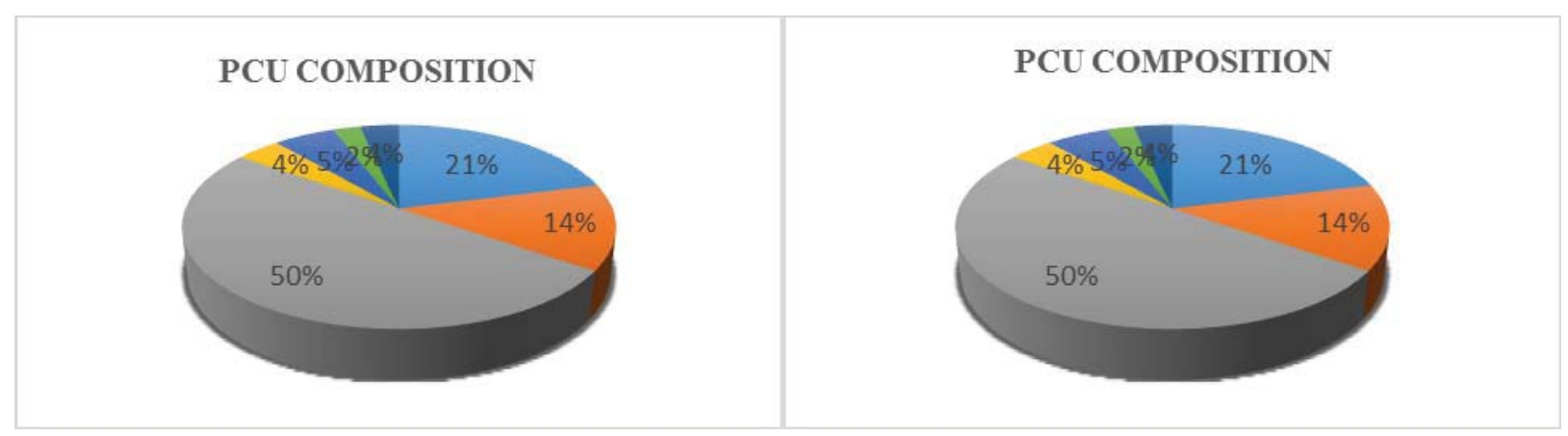

Figure 2: Pcu composition during entire day from Chaheru Figure 3: Pcu composition during entire day from Phagwara to Phagwara (Monday) to Chaheru (Monday)

\begin{tabular}{|l|l|}
\hline \multicolumn{2}{|c|}{ to Phagwara (Monday) } \\
PCU COMPOSITION
\end{tabular}

Figure 4: Pcu composition during entire day from Chaheru Figure 5: Pcu composition during entire day from Phagwara to Phagwara (Saturday) to Chaheru (Saturday)

From the above pie chart observations 4 wheelers shows 50\%-52\%, 2 wheelers show 20\%-21\%, 3 wheelers $14 \%$, LCV 3\%-4\%, Buses with 2 axles, 3 axles and $\mathrm{m}$ axles shows 5\%. 2\%, 4\% respectively. Thus we can say that people travel from bucolic areas of phagwara district concerning Jalandhar city for education and employment purposes.

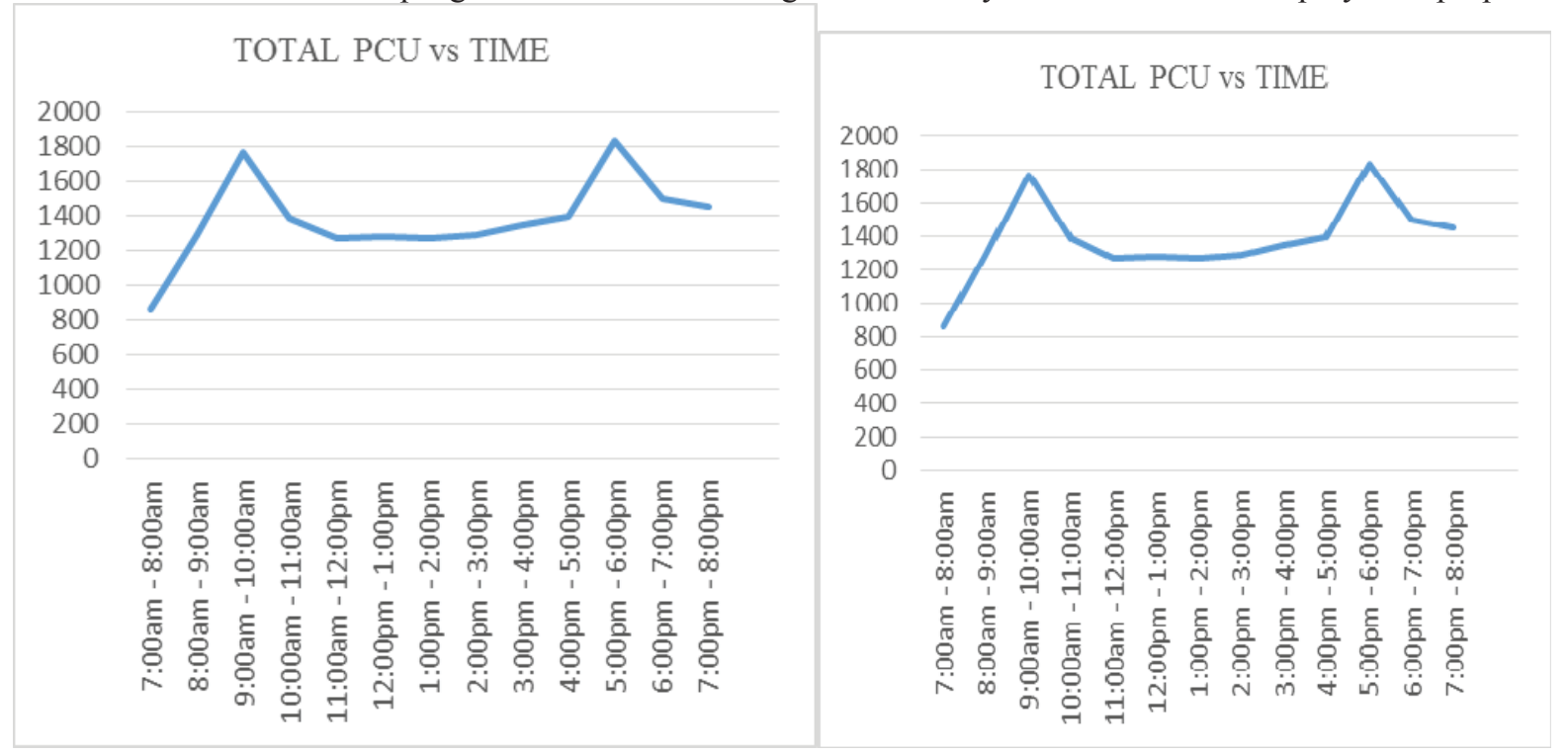

Figure 6: Variation of Classified Total PCU with Time From Chaheru to Phagwara (Monday)
Figure 7: Variation of Classified Total PCU with Time From Phagwara to Chaheru (Monday) 


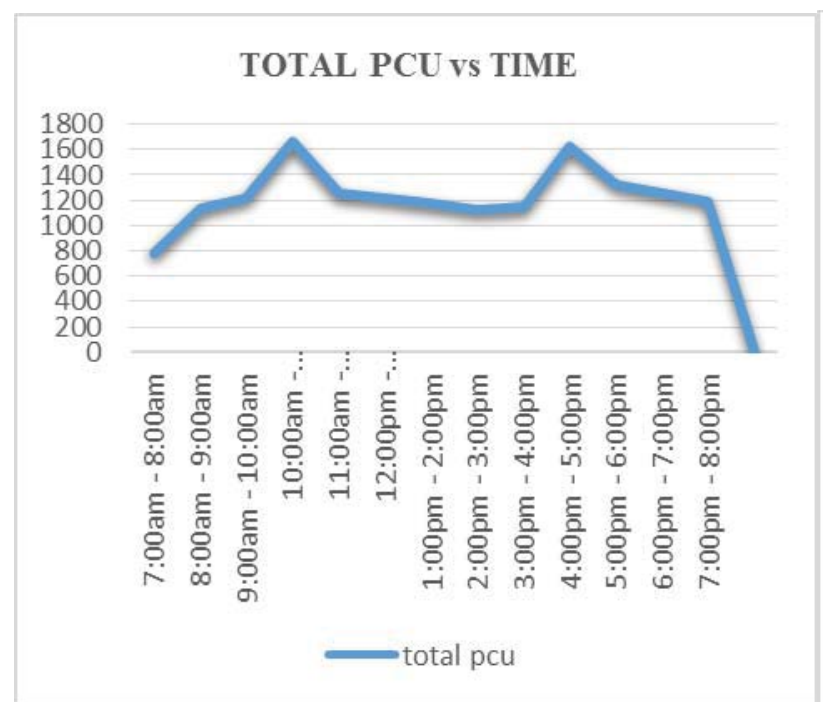

Figure 6: Variation of Classified Total PCU with Time From Chaheru to Phagwara (Monday)

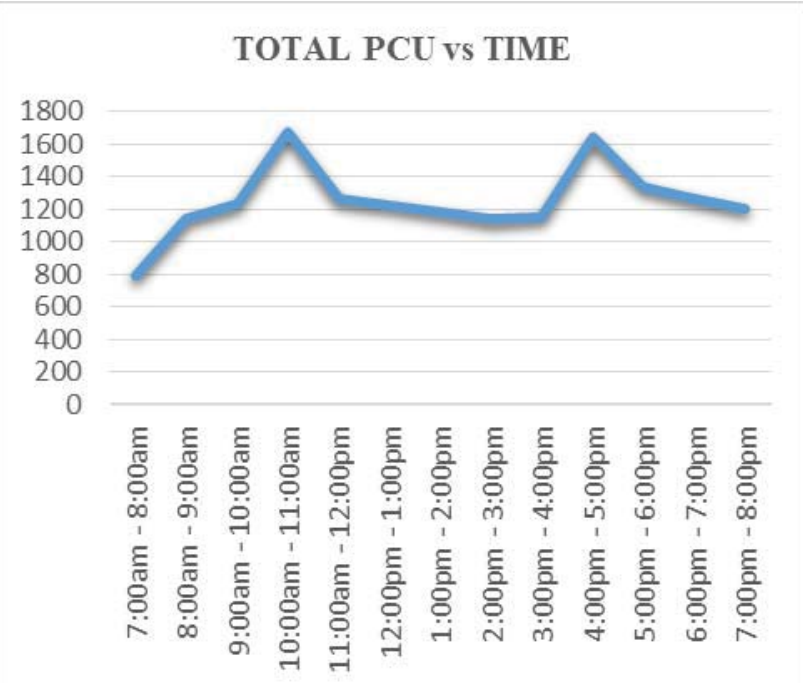

Figure 7: Variation of Classified Total PCU with Time From Phagwara to Chaheru (Monday)

From the above graphs we can see that the morning peak hour for week day i: e; Monday are 9:00am-10:00am and evening peak hour are 5:00pm-6:00pm and morning peak hour for weekend day i: e; Saturday are 10:am-11:00am and evening peak hour are 4:00pm-5:00pm.

\section{VII (B) CAPACITY AND LEVEL OF SERVICE}

Table 1: Calculation of V/C Ratio Traffic from both sides of traffic (Monday)

\begin{tabular}{|c|c|c|c|c|c|c|c|c|}
\hline Location & Direction & Time & PCU/Hour & $\begin{array}{l}\text { Width of } \\
\text { Road per } \\
\text { Lane (m) }\end{array}$ & $\begin{array}{l}\text { No. of } \\
\text { Lanes }\end{array}$ & $\begin{array}{l}\text { Design } \\
\text { Service } \\
\text { Volume } \\
\end{array}$ & $\begin{array}{c}\text { V/C } \\
\text { per } \\
\text { Ratio } \\
\end{array}$ & LOS \\
\hline \multirow{4}{*}{$\begin{array}{l}\text { National- } \\
\text { Highway } \\
\text { (NH-1) }\end{array}$} & \multirow[t]{2}{*}{$\begin{array}{c}\text { Towards } \\
\text { Phagwara }\end{array}$} & $\begin{array}{l}\text { Morning } \\
\text { Peak } \\
\text { Hour }\end{array}$ & 1769.8 & 3.5 & 3 & 2200 & .80 & $\mathrm{D}$ \\
\hline & & $\begin{array}{l}\text { Evening } \\
\text { Peak } \\
\text { Hour }\end{array}$ & 1833.05 & 3.5 & 3 & 2200 & .83 & $\mathrm{D}$ \\
\hline & \multirow[t]{2}{*}{$\begin{array}{l}\text { Towards } \\
\text { Chaheru }\end{array}$} & $\begin{array}{l}\text { Morning } \\
\text { Peak } \\
\text { Hour }\end{array}$ & 1769.8 & 3.5 & 3 & 2200 & .80 & $\mathrm{D}$ \\
\hline & & $\begin{array}{l}\text { Evening } \\
\text { Peak } \\
\text { Hour }\end{array}$ & 1833.05 & 3.5 & 3 & 2200 & .83 & $\mathrm{D}$ \\
\hline
\end{tabular}

From the above table, it clearly shows that the level of Service during morning and evening peak hours approaches to " $\mathrm{D}$ " with V/C ratio. Drivers are restricted in freedom to select speed or change lane. 
Table 2: Calculation of V/C Ratio Traffic from both sides of traffic (Saturday)

\begin{tabular}{|c|c|c|c|c|c|c|c|c|}
\hline Location & Direction & Time & PCU/Hour & $\begin{array}{l}\text { Width } \\
\text { of Road } \\
\text { per } \\
\text { Lane(m) }\end{array}$ & $\begin{array}{l}\text { No. of } \\
\text { Lanes }\end{array}$ & $\begin{array}{l}\text { Design } \\
\text { Service } \\
\text { Volume }\end{array}$ & $\begin{array}{l}\text { V/C } \\
\text { per } \\
\text { Ratio }\end{array}$ & LOS \\
\hline \multirow{4}{*}{$\begin{array}{l}\text { National- } \\
\text { Highway } \\
\text { (NH-1) }\end{array}$} & \multirow{2}{*}{$\begin{array}{c}\text { Towards } \\
\text { Phagwara }\end{array}$} & $\begin{array}{l}\text { Morning } \\
\text { Peak } \\
\text { Hour }\end{array}$ & 1669.45 & 3.5 & 3 & 2200 & .77 & $\mathrm{C}$ \\
\hline & & $\begin{array}{l}\text { Evening } \\
\text { Peak } \\
\text { Hour }\end{array}$ & 1634.8 & 3.5 & 3 & 2200 & .74 & $\mathrm{C}$ \\
\hline & \multirow[t]{2}{*}{$\begin{array}{l}\text { Towards } \\
\text { Chaheru }\end{array}$} & $\begin{array}{l}\text { Morning } \\
\text { Peak } \\
\text { Hour }\end{array}$ & 1669.45 & 3.5 & 3 & 2200 & .77 & $\mathrm{C}$ \\
\hline & & $\begin{array}{l}\text { Evening } \\
\text { Peak } \\
\text { Hour }\end{array}$ & 1634.8 & 3.5 & 3 & 2200 & .74 & $\mathrm{C}$ \\
\hline
\end{tabular}

From the above table, it clearly shows that the level of Service during morning and evening peak hours approaches to "C" with $\mathrm{V} / \mathrm{C}$ ratio. Drivers are acceptable for free flow or may be slightly restricted in freedom to select speed or change lane.

\section{SPOT SPEED STUDY}

The traffic speed data was conducted on Chaheru-Phagwara road. The data was collected during off-peak hour's i:e; 11:30am-01:00pm.

- A road stretch of $60 \mathrm{~m}$ was taken between Chaheru and Phagwara and spot study was conducted.

- Two observers were located at the two ends of the stretch separately observer having a stop watch.

- A sample of 10 (2 wheelers, 3 wheelers, Buses and Trucks) were surveyed.

- The data collected were analysed on an excel sheet and the speeds for each vehicle were calculated.

- Then the cumulative frequency curves were plotted to determine the percentile speed.

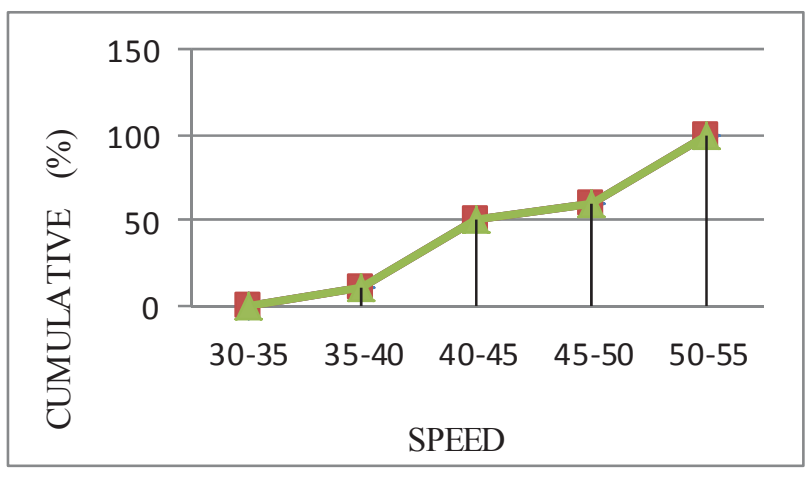

Figure 8: Cumulative Frequency Graph for Trucks.

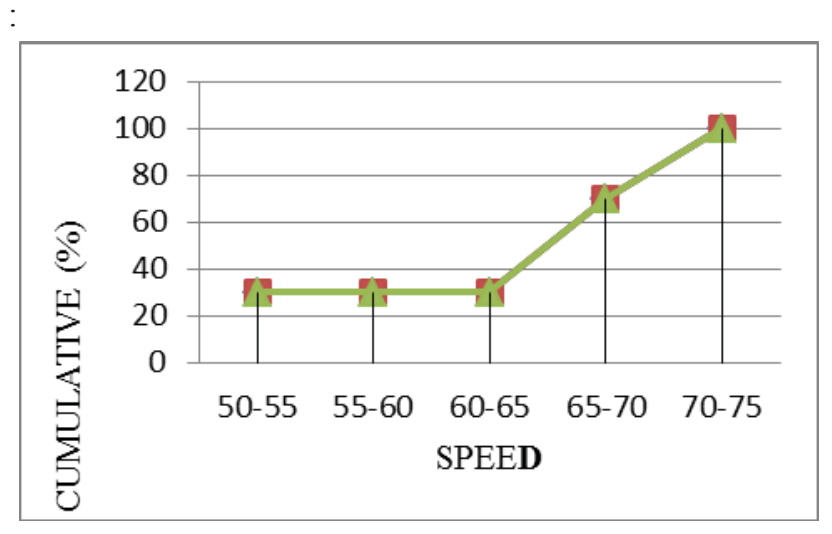

Figure 9: Cumulative Frequency Graph for Buses. 

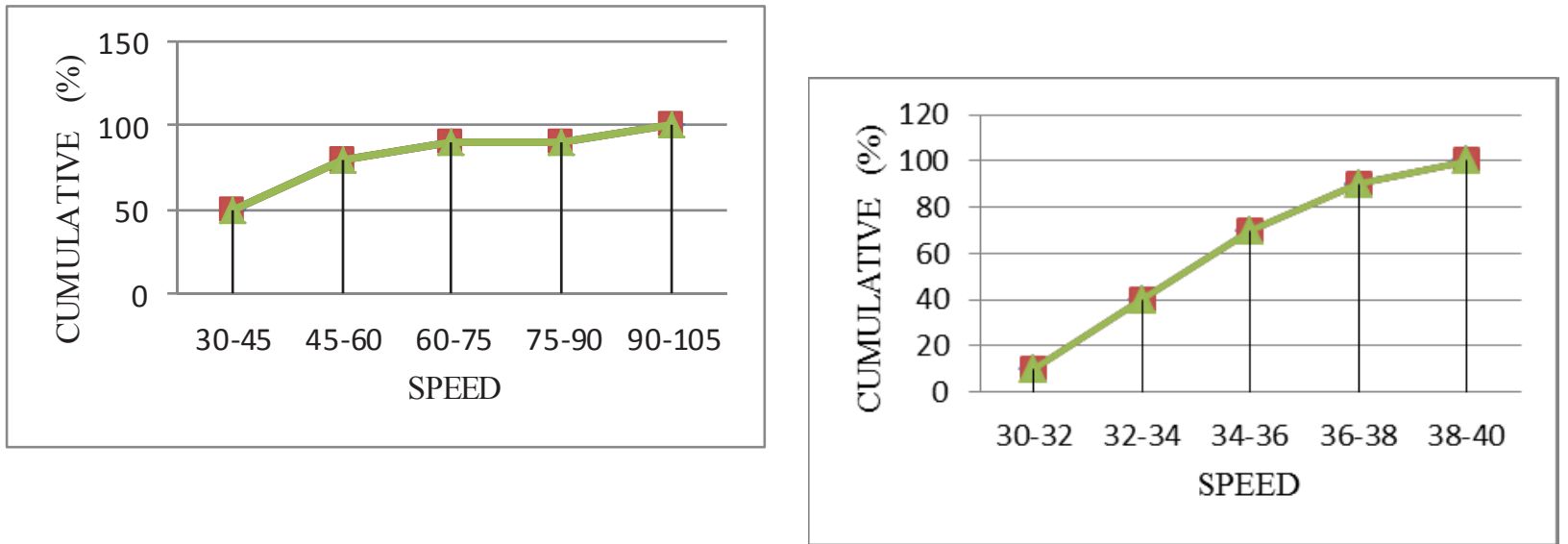

Figure 10: Cumulative Frequency Graph for 4 Wheelers. Figure 11: Cumulative Frequency Graph for 3 Wheelers.

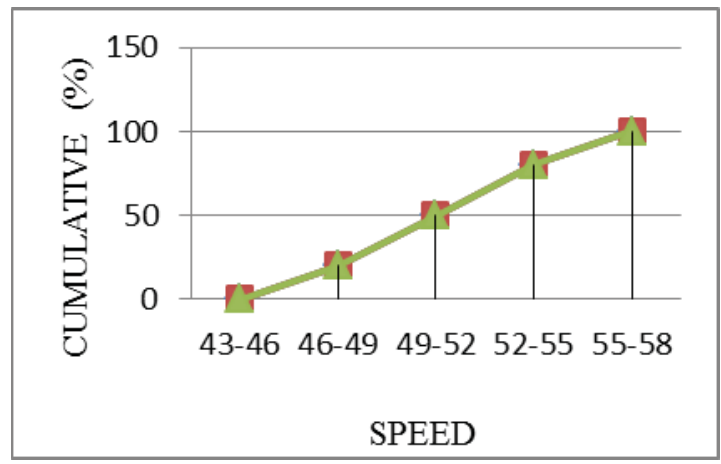

Figure 12: Cumulative Frequency Graph for 2 Wheelers. 


\section{Spot Speed Study}

Date: 01 August 2015.

Name: Sameer Ahmad Chadoo.

Location: NH-1 GT road phagwara.
Start Time: 11:30am

End Time: 01:00pm

Weather: Sunny.

TRUCKS

BUSES

\begin{tabular}{|c|c|c|c|c|c|c|c|}
\hline Dist. & Time & $\operatorname{Speed}(\mathrm{m} / \mathrm{s})$ & Speed $(\mathrm{km} / \mathrm{h})$ & Dist. & Time & $\operatorname{Speed}(\mathrm{m} / \mathrm{s})$ & Speed $(\mathrm{km} / \mathrm{h})$ \\
\hline 60 & 4.8 & 12.5 & 45 & 60 & 4 & 15 & 54 \\
\hline 60 & 4.5 & 13.3 & 48 & 60 & 3.2 & 18.8 & 67.5 \\
\hline 60 & 4.2 & 14.3 & 51.43 & 60 & 3.1 & 19.4 & 69.68 \\
\hline 60 & 5.3 & 11.3 & 40.75 & 60 & 3 & 20 & 72 \\
\hline 60 & 5.2 & 11.5 & 41.54 & 60 & 4.2 & 14.3 & 51.43 \\
\hline 60 & 5.5 & 10.9 & 39.27 & 60 & 4.1 & 14.6 & 52.68 \\
\hline 60 & 4.1 & 14.6 & 52.68 & 60 & 3.2 & 18.8 & 67.5 \\
\hline 60 & 4 & 15 & 54 & 60 & 3 & 20 & 72 \\
\hline 60 & 4.2 & 14.3 & 51.43 & 60 & 3 & 20 & 72 \\
\hline 60 & 5 & 12 & 43.2 & 60 & 3.2 & 18.8 & 67.5 \\
\hline
\end{tabular}

4 WHEELER

3 WHEELER

\begin{tabular}{|c|c|c|c|c|c|c|c|}
\hline Dist. & Time & Speed $(\mathrm{m} / \mathrm{s})$ & Speed $(\mathrm{km} / \mathrm{h})$ & Dist. & Time & Speed $(\mathrm{m} / \mathrm{s})$ & Speed $(\mathrm{km} / \mathrm{h})$ \\
\hline 60 & 4 & 15 & 54 & 60 & 6 & 10 & 36 \\
\hline 60 & 5 & 12 & 43.2 & 60 & 5.5 & 10.9 & 39.27 \\
\hline 60 & 5.2 & 11.5 & 41.54 & 60 & 5.9 & 10.2 & 36.61 \\
\hline 60 & 4.6 & 13 & 46.96 & 60 & 6.2 & 9.68 & 34.84 \\
\hline 60 & 2.3 & 26.1 & 93.91 & 60 & 6.5 & 9.23 & 33.23 \\
\hline
\end{tabular}




\begin{tabular}{|c|c|c|c|c|c|c|c|}
\hline 60 & 3 & 20 & 72 & 60 & 6.4 & 9.38 & 33.75 \\
\hline 60 & 4 & 15 & 54 & 60 & 6.7 & 8.96 & 32.24 \\
\hline 60 & 5.2 & 11.5 & 41.54 & 60 & 7 & 8.57 & 30.86 \\
\hline 60 & 5.1 & 11.8 & 42.35 & 60 & 6.2 & 9.68 & 34.84 \\
\hline 60 & 5.7 & 10.5 & 37.89 & 60 & 6.3 & 9.52 & 34.29 \\
\hline \multicolumn{8}{|c|}{2 WHEELER } \\
\hline Dist. & Time & Speed(m/s) & Speed $(\mathrm{km} / \mathrm{h})$ & Dist. & Time & $\operatorname{Speed}(\mathrm{m} / \mathrm{s})$ & Speed $(\mathrm{km} / \mathrm{h})$ \\
\hline 60 & 4 & 15 & 54 & 60 & 3.8 & 15.8 & 56.84 \\
\hline 60 & 4.3 & 14 & 50.23 & 60 & 4.5 & 13.3 & 48 \\
\hline 60 & 4.2 & 14.3 & 51.43 & 60 & 4.3 & 14 & 50.23 \\
\hline 60 & 4.1 & 14.6 & 52.68 & 60 & 4 & 15 & 54 \\
\hline 60 & 3.9 & 15.4 & 55.38 & 60 & 4.6 & 13 & 46.96 \\
\hline
\end{tabular}

From the above data, the percentile speeds for the vehicles can be interpreted as follows:

Table 4: Percentile Speed for the Vehicles

\begin{tabular}{|l|l|l|l|l|l|}
\hline \multirow{2}{*}{ Percentile } & \multicolumn{5}{|c|}{ SPEEDS (KMPH) } \\
\cline { 2 - 6 } & TRUCKS & \multirow{2}{*}{ BUSES } & $\begin{array}{c}4 \\
\text { WHEELERS }\end{array}$ & $\mathbf{3}$ WHEELERS & \multirow{2}{*}{ 2 WHEELERS } \\
\hline $98^{\text {th }}$ & 49.75 & 69.5 & 87 & 37.5 & 54.5 \\
\hline $85^{\text {th }}$ & 48 & 67.5 & 58 & 35.5 & 52.75 \\
\hline $50^{\text {th }}$ & 40 & 62.5 & 30 & 32.5 & 49 \\
\hline
\end{tabular}

\section{CONCLUSION}

The study analyzed that the volume of vehicles is $52 \%$ more than that of previous 10 years. As number of vehicles has increased much rapidly resulting in congestion. If same percentage of vehicles will grow in next 5 or 6 years then there will be serious congestion on the roadways and commuters will face very much difficulty. It is a clear message that the regulatory bodies will have to take a big leap, especially in terms of traffic management in cities like Phagwara. So we need to step up and bring a change on road capacity and maintain the proper level of service or reduce it to minimum. If more and more public transport are utilized, then there are more chances of reducing the Level of Service (LOS) to minimum level. From our study we had observed a LOS C and D. LOS C belongs to stable flow or near free flow but on the other hand LOS D is the approaching unstable flow in which speeds decreases while traffic increases, which is increasing the travel time of commuters and at times it causes headache to the drivers and commuters as well. 


\section{RECOMMENDATION}

- The traffic police mechanism system need to be reinforced, because during study we have observed the scarcity of law enforcement agency.

- Maintenance of road needs to be done so as to take commuters less travel time and smooth riding excellence.

- The roads, shoulders and medians should be designed according to the volume on the roads and type of vehicles.

- It has also been observed that no speed limit parameters were seen during the study, this needs to be implemented, so to help commuter's not to exceed beyond speed limits which will be increasing the accident rates and not to ride vehicles at lower speeds which results congestion.

- More focus should be given on public transport rather than private; this will help to reduce the congestion.

- Parking facilities need to be improved, which also acts as commuters more travel time and due to this congestion comes into picture.

- Public transport should be increased to reduce congestion, pollution, accident rate and travel time for commuters.

- Shoulders should be provided everywhere on the road, as in many portions shoulders were absent.

\section{REFERENCES}

[1] Web www.transportregionaloffice.com/jalandhar

[2] Arnott, R, and Small, K.A., (1994), “The Economics of Traffic clogging," American Scientist, Vol. 82, No. 5, pp. 446-455.

[3] Schrank, D.; Lomax, T. 2005. The 2005 Annual Urban Mobility Report. Texas: Texas Transportation Institute. 91 p.

[4] Khaled (2006). "Modelling Bus Priority Using Intermodal Dynamic Network Assignment-Simulation Methodology "Journal of Public Transportation, Vol. 9, No. 5, pp.1-22.

[5] Al-Ghamdi (1998), "Spot Speed Analysis on Urban roads in Riyadh". Transportation Research Board, Washington DC, 162-170. 